\title{
TEKANAN EKOLOGI DAN NILAI MONETER KARBON BIRU EKOSISTEM MANGROVE MUARA GEMBONG, TELUK JAKARTA
}

\section{ECOLOGICAL PRESSURE AND MONETARY VALUE OF BLUE CARBON MANGROVE ECOSYSTEM IN MUARA GEMBONG, JAKARTA BAY}

\author{
Terry Louise Kepel ${ }^{1}$, La Ode Nurman Mbay², R. Bambang Aditya Nugraha ${ }^{3}$, M. Hikmat Jayawiguna ${ }^{1}$, \\ Nasir Sudirman ${ }^{1}$, \& Peter Mangindaan ${ }^{1}$ \\ ${ }^{1}$ Pusat Riset Kelautan, Badan Riset dan Sumber Daya Manusia Kelautan dan Perikanan \\ Kementerian Kelautan dan Perikanan, \\ ${ }^{2}$ Kementerian Koordinator Bidang Kemaritiman dan Investasi \\ ${ }^{3}$ Direktorat Jasa Kelautan, Direktorat Jendral Pengelolaan Ruang Laut, Kementerian Kelautan dan Perikanan \\ e-mail : kepel@kkp.go.id
}

Diterima tanggal: 18 April 2021 ; diterima setelah perbaikan: 26 Agustus 2021 ; Disetujui tanggal: 3 September 2021

\begin{abstract}
ABSTRAK
Muara Gembong merupakan daerah yang mengalami tekanan antropogenik yang memberikan dampak signifikan bagi ekosistem pesisir di wilayah Teluk Jakarta. Riset ini bertujuan untuk menilai kondisi ekosistem mangrove, menghitung biomasa dan jumlah karbon yang tersimpan di dalam vegetasi mangrove per satuan luas (hektar) guna menentukan nilai moneternya. Riset dilakukan dengan pengamatan dan pengukuran mangrove untuk mengidentifikasi jenis mangrove, jumlah tegakan serta mengukur diameter batang pohon mangrove. Hasil riset menunjukkan bahwa rata-rata biomass dan karbon yang tersimpan di ekosistem mangrove Muara Gembong adalah sebesar 258,81 Mg/ha dan 119,97 Mg C/ha. Potensi kehilangan nilai ekonomi akibat kehilangan karbon ditaksirkan berkisar antara 1,15-2,84 x $10^{11}$ rupiah atau setara dengan 2,7-6,7 milyar per tahun. Kondisi kerusakan diperparah dengan adanya serangan hama, abrasi dan sampah. Dibutuhkan skenario rehabilitasi dengan memperhitungkan luasan area mangrove yang terdampak serta besarnya nilai kerugian moneter akibat kerusakan dan jasa ekosistem mangrove yang hilang.
\end{abstract}

Kata kunci: Tekanan ekologi, nilai moneter, karbon biru, Muara Gembong.

\section{ABSTRACT}

Muara Gembong is experiencing anthropogenic pressure, which significantly impacts the coastal ecosystem in the Jakarta Bay area. This research aims to assess the condition of the mangrove ecosystem, calculate the biomass and the amount of carbon stored in the mangrove vegetation per unit area (hectare) to determine its monetary value. The research was conducted by observing and measuring mangroves to identify mangrove species, number of stands and measure the diameter of mangrove tree trunks. The results showed that the average biomass and carbon stored in the Muara Gembong mangrove ecosystem was $258.81 \mathrm{Mg} / \mathrm{ha}$ and $119.97 \mathrm{Mg} \mathrm{C/}$ ha. The potential loss of economic value due to carbon loss is estimated to be between $1.15-2.84 \times 10^{11}$ rupiahs or equivalent to $2.7-6.7$ billion per year. The condition of damage was exacerbated by pest attacks, abrasion and solid waste. Moreover, land conversion and garbage also become problems. Therefore, a rehabilitation scenario is needed that considers the extent of the affected mangrove area and the amount of monetary loss due to the damage and loss of mangrove ecosystem services.

Keywords: Ecological pressure, monetary value, blue carbon, Muara Gembong. 


\section{PENDAHULUAN}

Mangrove, komunitas tumbuhan berbunga yang tumbuh dan berkembang di daerah pantai yang mengalami pasang surut. Ekosistem mangrove ini sering disebut sebagai hutan pasang surut (tidal forest), hutan kayu pantai (coastal woodland), hutan payau, mangal dan hutan bakau. Ekosistem mangrove tersebar mulai dari daerah tropis sampai sub tropis.

Secara ekologis ekosistem mangrove mempunyai fungsi yang beragam. Mangrove menjadi tempat hidup (nursery ground) dan memijah (spawning ground) bagi banyak organisme laut seperti ikan, udang-udangan, kerang dan sebagainya ataupun tempat bersembunyi dari serangan predator. Karena itu mangrove adalah salah satu wilayah yang paling produktif di daerah pesisir (Alongi, 2014). Biodiversitas yang ada di mangrove membuat ekosistem ini menjadi sumber makanan bagi penduduk yang hidup di sekitarnya. Ekosistem mangrove juga mempunyai fungsi untuk perangkap dan stabilisasi sedimen, peredam ombak dan gelombang. Ekosistem mangrove juga dikenal sebagai ekosistem yang menyerap dan menyimpan karbon organik yang tinggi dengan kapasitas lima kali lebih besar daripada hutan hujan tropis (donato et al, 2011; Alongi, 2014). Simpanan karbon ini kemudian disebut dengan istilah karbon biru. Hal ini membuat ekosistem mangrove mendapat perhatian dalam upaya mitigasi perubahan iklim. Seluruh fungsi mangrove di atas kemudian dikenal sebagai jasa ekosistem.

Kontinuitas penyediaan jasa ekosistem ini akan setidaknya bergantung pada kestabilan ekosistem. Sementara itu, kestabilan ekosistem banyak dipengaruhi oleh gangguan atau tekanan terhadap ekosistem ini (baik intensitas dan besaran) serta daya tahan (resilience) ekosistem ini terhadap gangguan yang ada. Daya tahan akan sangat bergantung pada kemampuan ekosistem ini untuk beradaptasi dengan perubahan-perubahan yang terjadi akibat tekanan.

Berdasarkan IPCC 2007 (AR4), Brown et al. (2014a) membagi gangguan atau tekanan di daerah pesisir menjadi 2 bagian yaitu gangguan karena pengaruh perubahan iklim dan pengaruh antropogenik. Perubahan iklim memicu terjadinya kenaikan muka air laut, presipitasi ekstrim, peningkatan $\mathrm{CO}_{2}$, suhu, gelombang dan badai. Sedangkan antropogenik, yaitu peningkatan populasi, penggunaan lahan, pengelolaan air, faktor ekonomi dan penurunan tanah (subsidence) karena eksploitasi air tanah berlebih.
Apabila terjadi perubahan pada ekologi akibat gangguan yang ada ini maka selain terjadi penurunan kualitas pada jasa ekosistem juga dapat berdampak pada penurunan nilai moneter dari ekosistem tersebut. Dalam prespektif perubahan iklim, menurunnya luasan mangrove dapat berakibat pada terlepasnya karbon yang tersimpan di vegetasi. Apabila jumlah terlepasnya karbon ini divaluasi secara moneter maka dapat diestimasi nilai kerugiannya. Muara Gembong yang terletak di Teluk Jakarta merupakan daerah yang mengalami tekanan antropogenik yang memberikan dampak signifikan bagi ekosistem pesisir. Apalagi wilayah ini secara langsung dan tidak langsung dipengaruhi oleh aliran sungai Citarum dan air Teluk Jakarta. Penambangan pasir, sampah dan menurunnya luasan ekosistem mangrove merupakan berbagai tekanan yang teridentifikasi di sana.

Tujuan dari penelitian ini adalah deskripsi kondisi ekologis mangrove di Muara Gembong termasuk potensi tekanan yang ada serta estimasi nilai karbon biru dari biomasa mangrove termasuk potensi perubahannya.

\section{BAHAN DAN METODE}

\section{Lokasi}

Penelitian dilakukan di ekosistem mangrove Pantai Muara Beting serta Pulau Buaya dan Pulau Mekar yang berada di Pantai Mekar Kecamatan Muara Gembong (555,667'LS; $\left.107^{\circ} 3,247^{\prime} \mathrm{BT}\right)$. Dinamika wilayah pesisir di kecamatan Muara Gembong ini sangat tinggi. Di bagian utara yang langsung menghadap Teluk Jakarta cenderung mengalami abrasi yang kemudian mengakibatkan kerusakan ekosistem, banjir rob, rusaknya tambak dan lahan rumah milik penduduk desa. Namun di sisi barat kecamatan ini terjadi sedimentasi yang menambah luasan wilayah pesisir.

\section{Pengambilan Data dan Analisis}

Pengukuran dilakukan dengan menarik transek garis sepanjang $100 \mathrm{~m}$ dari kumpulan mangrove terluar (di pantai) ke arah dalam (daratan) secara tegak lurus. Apabila lebar habitat mangrove tidak mencapai 100 $\mathrm{m}$ maka transek ditarik sampai ke batas mangrove terakhir. Sepanjang garis transek, dibuat kuadrat 10x10 $\mathrm{m}$ dari tali dengan jarak antar kuadrat sepanjang 10 m.Selanjutnya dilakukan identifikasi jenis mangrove,, penghitungan jumlah tegakan pohon serta dilakukan pengukuran Diameter Breast High (DBH) pohon. Informasi yang ada dicatat di dalam log book. Data yang ada kemudian dianalisis untuk mendapatkan informasi ekologia termasuk kerapatan dan indeks nilai 

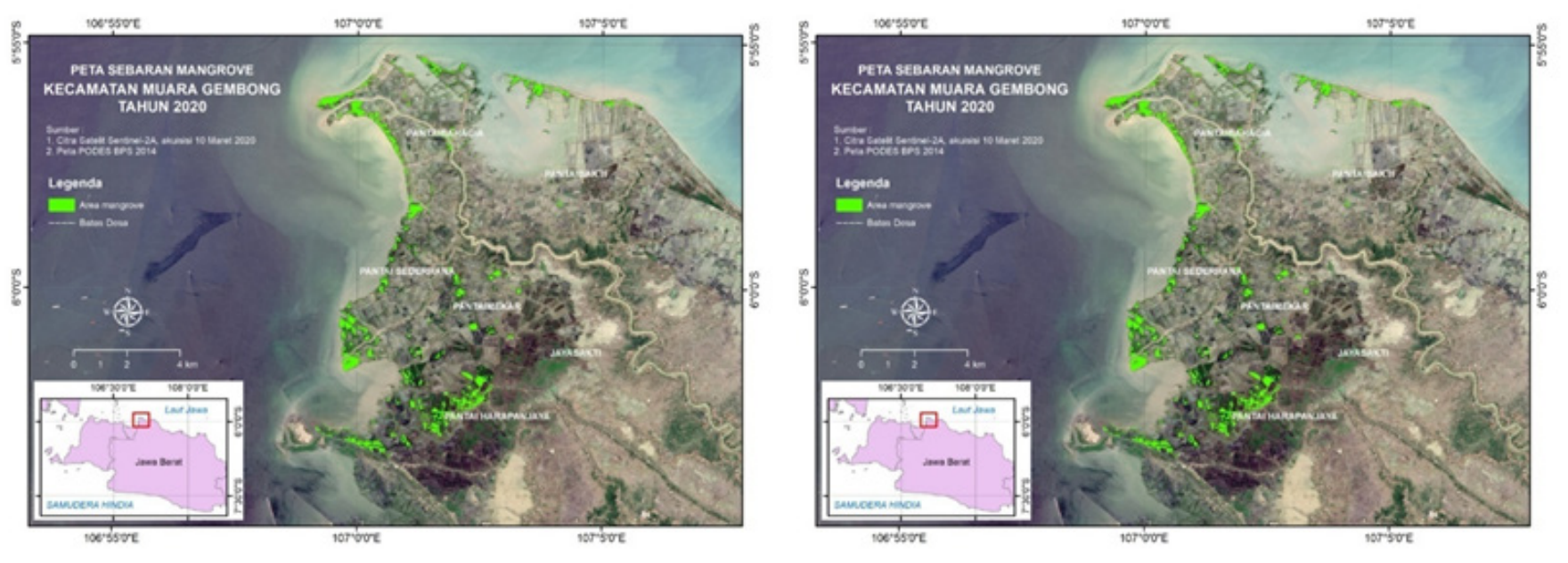

Gambar 1. Peta Lokasi Penelitian.

Figure 1. Research Location Map.

penting.

Untuk mendapatkan gambaran umum tentang potensi tekanan yang ada di ekosistem mangrove maka dilakukan pengamatan visual bersamaan dengan kegiatan pengukuran. Beberapa parameter yang dinilai antara lain adalah kematian vegetasi, penebangan pohon, abrasi sedimen dan timbulan. Hasil pengamatan dianalisa secara deskriptif.

Perhitungan karbon biru atau simpanan karbon terutama di bagian vegetasi menggunakan metode non-destruktif yaitu dengan melakukan pendekatan berdasarkan alometrik. Alometrik yang digunakan bersifat spesies-spesifik (Tabel 1). Beberapa parameter yang biasanya dipakai dalam perhitungan ini adalah diameter $(\mathrm{DBH})$, densitas pohon dan atau tinggi pohon.

\section{HASIL DAN PEMBAHASAN}

\section{Kondisi Mangrove}

Secara fungsional, mangrove di lokasi penelitian termasuk kategori fringe mangrove yang mengalami pasang surut harian (Gambar 2). Di Muara Beting, Avicennia marina merupakan satu-satunya jenis mangrove yang terukur dalam transek. Namun demikian, ada dua spesies lain yang teridentifikasi hadir dengan jumlah yang sangat sedikit yaitu Rhizophora mucronata, Sonneratia alba. A.marina juga ditemukan dominan di Pulau Kuntul namun di Pulau Buaya spesies dominan adalah $A$. alba. Dominasi kedua spesies ini terukur dari nilai INP sebesar 265 untuk A. marina di Pulau Kuntul dan A. alba sebesar 249 di Pulau Buaya. Kondisi dominasi $A$. alba juga teridentifikasi di Pantai Mekar (Rahmasari et al., 2019). Spesies mangrove lain yang ditemukan di kedua lokasi ini adalah $R$. mucronata, S. alba, Ceriops tagal dan nipah.

Kondisi dominasi spesies Avicennia ini secara alami umumnya terlihat di sepanjang pantura Jawa mulai dari Serang, Muara Kamal, Indramayu dan Pati. Van Steenis (1958) dan Kantor Menteri Negara Lingkungan Hidup (1993) melaporkan bahwa A. marina, A. alba dan $R$. mucronata merupakan spesies yang dominan di Jawa Barat (Giesen et al. 2006). Nguyen et al. (2017) menemukan bahwa regenerasi alami A. marina di Kabupaten Brebes, tumbuh lebih cepat dibandingkan dengan $R$. mucronata hasil penanaman.

Dari tiga lokasi penelitian, kerapatan rata-rata pohon mangrove di Muara Beting paling tinggi yaitu sebesar 4.025 pohon/ha diikuti Pulau Kuntul 2280 pohon/

Tabel 1. Persamaan allometrik untuk perhitungan biomass bagian atas mangrove Table 1. Allometric equations for aboveground biomass

\begin{tabular}{lll}
\hline Jenis & Persamaan & Sumber \\
\hline Avicennia alba & $\mathrm{B}=0,1848$ (D)2,3524 & Dharmawan \& Siregar, 2008 \\
Avicennia marina & $\mathrm{B}=0,1848$ (D)2,3524 & Dharmawan \& Siregar, 2008 \\
Rhizophora mucronata & $\mathrm{B}=0,128(\mathrm{D}) 2,60$ & Fromard et al, 1998 \\
\hline
\end{tabular}



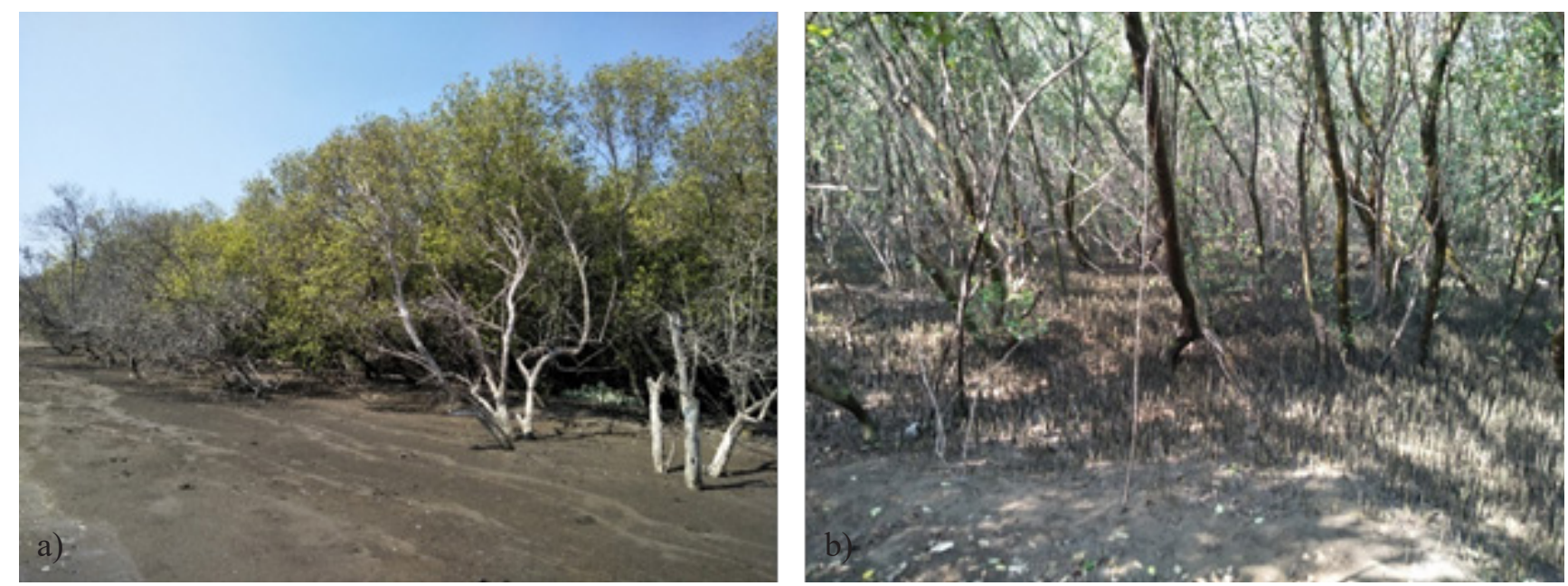

Gambar 2. Fringe mangrove Muara Beting yang didominasi oleh A. marina. a) Bagian depan kawasan mangrove; b) bagian dalam.

Figure 2. Muara Beting mangrove fringe dominated by A. marina. a) The front of the mangrove area; $b)$ the inside.

ha dan Pulau Buaya 500 pohon/ha. Besar diameter pohon di ketiga lokasi berbanding terbalik dengan kerapatan pohon, semakin besar kerapatan maka semakin kecil diameter rata-rata. Dengan kerapatan yang tinggi, rata-rata diameter pohon di Muara Beting lebih kecil dibandingkan dengan dua lokasi lain yaitu sebesar 9.62 44,67. Nilai diameter di Pulau Kuntul dan Pulau Buaya berturut-turut sebesar 12,23 $\pm 0,65$ dan $17,05 \pm 1,31$.

\section{Potensi Tekanan}

Secara visual, kondisi mangrove Muara Beting di bagian depan yang menghadap laut dengan bagian dalam terlihat sangat berbeda. Mangrove yang berada di sisi depan terlihat mengalami kematian (Gambar 3) ditandai dengan pohon dengan daun yang menguning, pohon kering tanpa daun (standing dead tree) serta pohon mati yang tumbang (uprooted) (Gambar 3). Beberapa pohon (baik hidup dan mati) terlihat memiliki lubang di sepanjang batang utama (Gambar 4). Sedimen di depan mangrove berupa pasir dan semakin ke dalam, sedimen bercampur lumpur. Pada saat pasang, air laut masuk melalui sebuah saluran kecil yang berada di sisi barat.

Penyebab kematian mangrove di daerah ini diduga akibat 3 hal yaitu abrasi pantai, serangan hama dan tumpahan minyak. Abrasi kawasan pesisir dapat terjadi karena beberapa faktor seperti kondisi oseanografi (gelombang dan arus), klimatologi (angin, hujan), ketidakseimbangan neraca sedimen serta aktivitas manusia yang mengubah fungsi lahan. Kawasan pantai
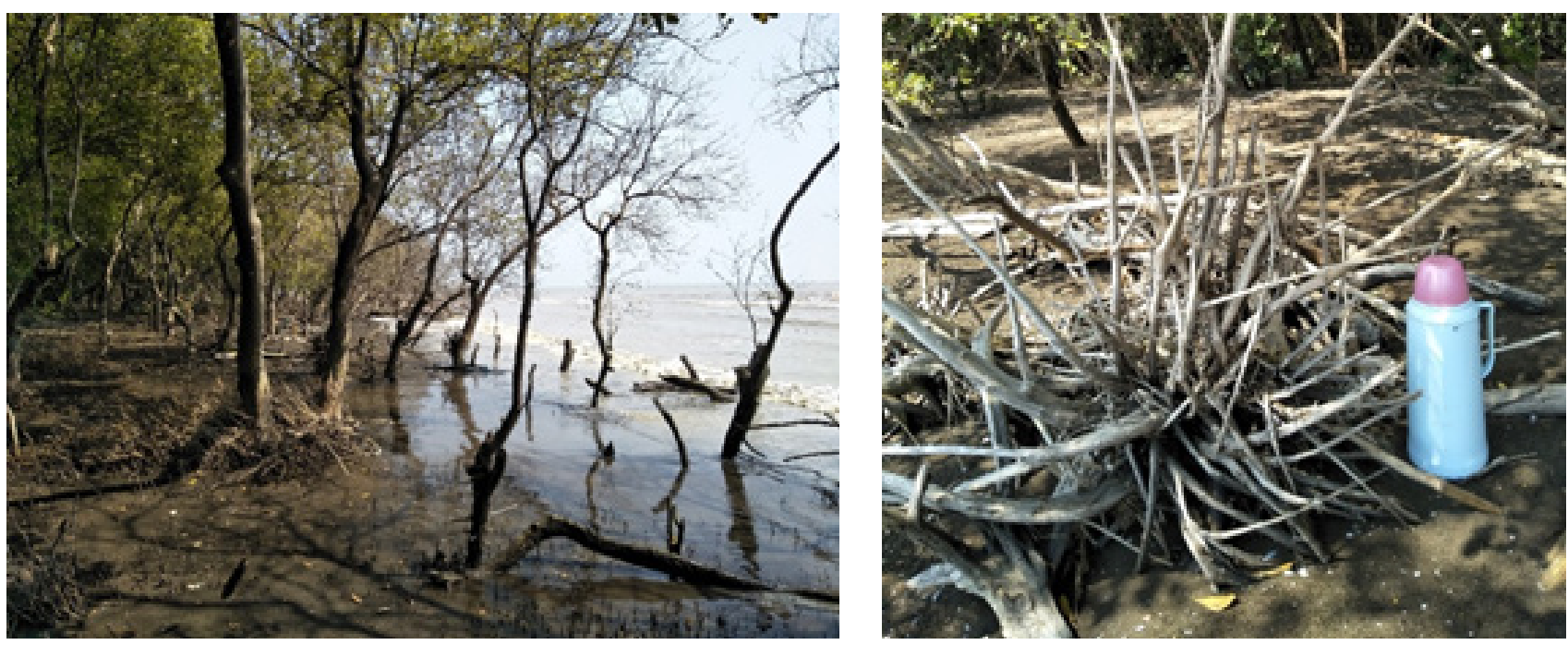

Gambar 3. Kondisi pohon mangrove bagian depan yang mati.

Figure 3. Condition of dead front mangrove trees. 

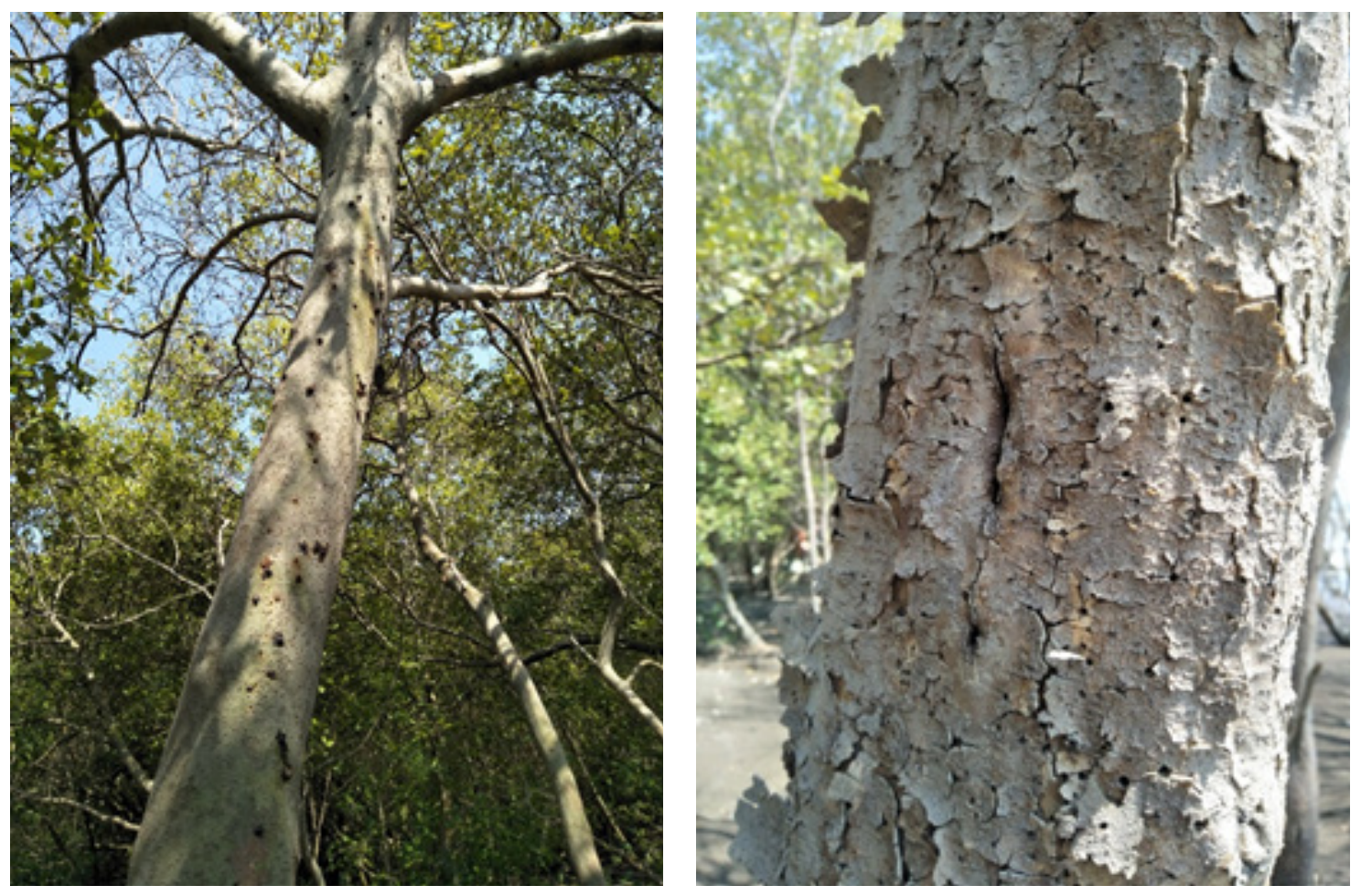

Gambar 4. Lubang di batang pohon.

Figure 4. Holes in tree trunks.

Muara beting mengalami abrasi yang sangat masif akibat perubahan lahan. Lahan yang tadinya tambak dan mangrove menjadi terbuka dan didominasi oleh air namun dengan kedalaman yang dangkal.

Hama merupakan salah satu gangguan alamiah pada mangrove selain topan, tsunami, banjir dan penyakit (Alongi, 2009). Hama pada mangrove dapat menyerang batang, cabang dan daun. Ada 9 jenis hama yang teridentifikasi menyerang mangrove di Kecamatan Batu Ampar, Kubu Raya, Kalimantan Barat yaitu ulat kantong pagoda (Pagodiellaspp.), ulat kantong (Acanthopsychesp.), krama (Episesarmaspp.), kumbang penggerek (Xanthochroasp.), kutu daun, teritip (Balanus amphitrite), saranglaba-laba, keong (Kelas Gastropoda), dan siput tanpa cangkang (Vaginulableekeri) (Haneda \& Suheri, 2018).

Ulat kantong biasanya menyerang daun dan menyebabkan banyak lubang di daun. Dari penduduk lokal didapatkan informasi bahwa serangan hama daun membuat daun mangrove berlubang, berwarna kuning dan atau gugur. Fenomena ini biasanya hanya terjadi pada musim-musim tertentu atau beberapa bulan dalam setahun. Fenomena matinya pohon mangrove di Muara Gembong (Pantai Mekar) akibat serangan ulat bulu juga dilaporkan oleh kelompok sadar wisata desa setempat pada Agustus 2019 (Warsono, 2019). Hama yang menyerang batang dan cabang mangrove adalah rayap Prorhinotermes sp (Haneda \& Suheri, 2018).

Selain tekanan abrasi dan hama, mangrove di Tanjung Muara Beting juga mengalami tekanan polusi akibat tumpahan minyak yang berasal dari kilang minyak yang bocor di Karawang. Karena jarak yang relatif dekat dan pola arah arus, tumpahan minyak ini sampai di Tajung Beting (Gambar 4). Di lokasi, tumpahan minyak hanya terlihat di bagian luar tidak masuk sampai ke mangrove bagian dalam. Tumpahan minyak di area mangrove dapat menyebabkan daun menjadi kuning (yellowing), berbintik (spots), berjatuhan (defoliating), berlubang (perforation), memutar (twisting) dan memudar (fading); perubahan densitas dan distribusi vegetasi dan hewan (Getter et al, 1981; Kairo et al, 2005). Dalam jangka panjang, biasanya lebih dari 1 tahun, tumpahan minyak dapat menyebabkan kematian pada pohon (Duke, 2016). Pada pohon-pohon yang tidak mengalami kematian (lethal impact) maka biasanya akan menjadi organisme yang sangat rentan (sub-lethal impact) terhadap berbagai tekanan seperti polusi dan hama.

Berbeda dengan Muara Beting, tekanan ekologis di Pulau Buaya dan Pulau Kuntul terlihat pada rendahnya jumlah semai dan anakan yang ditemukan. Tingginya konversi lahan diduga menjadi salah satu faktor yang 
secara tidak langsung mempengaruhi pola hidrologi perairan, inundasi dan salinitas. Pola hidrologi yang berubah akan menghambat rekruitmen mangrove secara alami. Rekruitmen mangrove sangat bergantung pada kondisi hidrologi (Brown et al, 2014b; Sidik et al, 2019). Tekanan lain yang terlihat di Pulau Buaya dan Pulau Kuntul adalah timbulan sampah terutama plastik. Timbulan plastik berupa sampah rumah tangga yang kemungkinan besar berasal dari aliran anak sungai Citarum.

\section{Karbon Biru Muara Gembong}

Berdasarkan pengukuran data lapangan yang dilakukan di Muara Beting (2019), Pulau Buaya dan Pulau Kuntul (2018) maka rata-rata biomas dan karbon yang tersimpan di ekosistem mangrove Muara Gembong adalah sebesar 258,81 Mg/ha dan 119,97 Mg C/ha secara berturut-turut (Tabel 2). Simpanan biomas dan karbon di Pulau Kuntul lebih tinggi dibandingkan dengan dua lokasi yang lain. Apabila dibandingkan dengan simpanan karbon di wilayah Teluk Miskam, Banten, Pulau Kemujan - Karimunjawa, beberapa wilayah di Sulawesi Utara (Ratatotok, Lembeh dan Kema), maka karbon vegetasi di Muara Gembong lebih tinggi (Atidkk, 2014; Cahyaningrum et al., 2014; Hartoko et al., 2015; Kepel et al., 2017; Kepel et al., 2019). Namun ada juga daerah yang memiliki karbon vegetasi yang lebih tinggi yaitu mangrove Ciasem-Jawa Barat, Bintuni, Timika dan Sembilang (Dharmawan \& Siregar, 2008; Murdiyarso et al., 2015).
Nilai simpanan karbon biru di mangrove akan menjadi lebih besar lagi apabila memperhitungkan sedimen. Secara rata-rata, nilai karbon di sedimen akan beberapa kali lebih besar dibandingkan dengan komponen penyimpan karbon (carbon pool) yang lain seperti vegetasi dan serasah. Namun demikian, estimasi karbon sedimen di Muara gembong belum dilakukan.

Berubahnya tutupan mangrove baik bertambah karena rehabilitasi maupun berkurang karena berbagai tekanan lingkungan dan manusia akan menyebabkan perubahan simpanan karbon di vegetasi dan bahkan di sedimen. Hasil perhitungan luasan mangrove berdasarkan analisa citra Landsat kegiatan riset tahun 2019 terlihat adanya penurunan. Tahun 1976, luas mangrove di Muara Gembong sebesar 2.308 ha sedangkan pada tahun 2018 tersisa 888,75 ha. Artinya telah terjadi penurunan luasan sebesar $38,5 \%$. Apabila nilai simpanan ratarata karbon $(119,97 \mathrm{Mg} \mathrm{C} / \mathrm{ha})$ diproyeksikan pada penurunan luasan ini maka karbon yang terlepas adalah sebesar 170.267 Mg C.Nilai ini setara dengan 624.881 $\mathrm{Mg} \mathrm{CO}$ e.

\section{Nilai Moneter Karbon Biru}

Secara global, karbon biru belum diperhitungkan di dalam mekanisme pembayaran emisi yang dihindari (avoided emission) atau peningkatan cadangan bahkan belum masuk di dalam mekanisme perdagangan karbon (carbon market) (Murray et al., 2011). Apabila karbon biru ini dimasukkan ke dalam salah satu skema seperti pasar wajib atau sukarela maka dapat dipastikan

Tabel 2. Biomas dan simpanan karbon pohon mangrove Muara Gembong

Table 2. Biomass and carbon storage of Muara Gembong mangrove trees

\begin{tabular}{lllll}
\hline & Pulau Buaya & Pulau Kuntul & Muara Beting & Rata-Rata \\
\hline Biomass (Mg/ha) & 117,14 & 342,82 & 316,47 & 258,81 \\
Karbon (Mg C/ha) & 53,90 & 159,31 & 146,69 & 119,97 \\
\hline
\end{tabular}

Tabel 3. Contoh harga karbon di pasar karbon

Table 3. Examples of carbon prices in the carbon market

\begin{tabular}{lll}
\hline Pasar & Harga $\left(\mathbf{R p} / \mathbf{M g ~ C O}_{2} \mathbf{e}\right)$ & Sumber Data \\
\hline EU Emission Trading & 365.196 & https://markets.businessinsider.com/commodi \\
System (EU ETS) & & ties/co2-european-emission-allowances \\
& & Diakses : November 2019 \\
CDM & 260.960 & Murray et al., 2011 \\
Social Coast of & 644.046 & Jerath et al., 2016 \\
Carbon (SCC) & & \\
\hline
\end{tabular}


harga karbon untuk setiap pasar tersebut berbeda-beda. Menurut World Bank et al. (2017), harga karbon yang teridentifikasi bervariasi antara US\$ 1 - US\$ $140 / \mathrm{Mg}$ $\mathrm{CO}_{2} \mathrm{e}$. Harga karbon sangat dipengaruhi oleh kebijakan nasional atau regional, faktor sosio-ekonomi serta teknologi (Jerath et al., 2016). Beberapa contoh harga karbon yang ada ditampilkan dalam Tabel 2. Harga ini telah dikonversikan ke rupiah berdasarkan kurs yang berlaku (Eur 1 = Rp 15.600; US\$ $1=$ Rp 14.000).

Apabila potensi kehilangan minimal karbon akibat menurunnya luasan mangrove di Muara Gembong diproyeksikan pada harga karbon yang ada ini, maka potensi kehilangan nilai ekonomi berkisar antara $1,15-2,84 \times 10^{11}$ rupiah. Apabila dirata-ratakan maka kehilangan nilai ekonomi akibat kehilangan karbon per tahun sebesar 2,7 - 6,7 milyar rupiah. Angka yang dihasilkan ini merupakan nilai konservatif.

Prayogi et al. (2017) melakukan valuasi ekonomi terhadap manfaat langsung dan tidak langsung ekosistem mangrove di Desa Pantai Mekar, Muara Gembong. Hasil yang didapatkan bahwa dalam setahun manfaat yang didapatkan dari ekosistem mangrove mencapai Rp 101,354 miliar/tahun. Angka ini sudah termasuk nilai stok karbon sebesar Rp 531.015.534.

\section{Skenario Biaya Rehabilitasi}

Akibat rusaknya ribuan hektar lahan mangrove di Muara Gembong ini maka diusulkan untuk mengadakan rehabilitasi. Rehabilitasi ini merupakan bentuk kompensasi untuk mengembalikan jasa lingkungan yang sudah terdegradasi dan menjadi langkah awal penetapan daerah konservasi. Berdasarkan hasil riset Pusat Riset Kelautan - BRSDM KKP tahun 2018 maka diusulkan lahan rehabilitasi sebesar 1.000 ha sebagai kompensasi kerusakan dengan biaya sebesar Rp 30.658.191.000,-. Nilai ini akan bertambah apabila dimasukkan pada skenario biaya penetapan daerah konservasi (marine protected area) dan biaya manajemennya (McCrea-Strub et al., 2011; Murry et al., 2011).

Menurut McCrea-Strub et al. (2011), biaya penetapan daerah konservasi berkisar antara US\$20 - US\$ 788, dengan rata-rata sebesar US\$232/ha atau Rp 3.248.000 per ha. Adapun biaya pengelolaan adalah sebesar US\$ 25- 100/ha tergantung dari tipe negaranya(Murray et al., 2011). Semakin makmur suatu negara maka harga pengelolaannya akan semakin tinggi. Perhitungan biaya pengelolaan menggunakan harga US\$ $50 /$ ha atau sebesar Rp 700.000/ha. Dengan skenario rehabilitasi ditambah dengan penetapan kawasan konservasi dan biaya pengelolaan ini maka total biaya yang harus dikeluarkan sebesar: $\mathrm{Rp}$ 30.658.191.000,- + Rp $3.579 .296 .000+700.000 .000=\operatorname{Rp} 35.008 .887 .000,-$.

\section{KESIMPULAN DAN SARAN}

Ekosistem mangrove di Muara Gembong telah lama mengalami tekanan baik dari faktor alam maupun manusia. Terjadinya serangan hama dan proses abrasi di beberapa bagian pantai Muara Gembong menyebabkan kematian dan tumbangnya pohon-pohon mangrove. Kondisi ini diperparah dengan masuknya tumpahan minyak yang berasal dari kilang minyak yang bocor. Selain itu, proses perusakan mangrove beberapa dekade lalu telah membuat turunnya luasan mangrove sampai mencapai sekitar seribu hektar.

Kondisi degradasi ekosistem ini juga menurunkan kualitas jasa ekosistem yang ada, salah satunya adalah jasa penyimpan karbon yang dikenal sebagai karbon biru. Lepasnya karbon di Muara Gembong ini adalah sebesar $120.327 \mathrm{Mg} \mathrm{C}$ atau setara dengan $441.600 \mathrm{Mg}$ $\mathrm{CO}_{2}$ e. Kehilangan moneter yang terjadi berkisar antara $1,15-2,84 \times 10^{11}$ rupiah. Apabila dirata-ratakan maka kehilangan nilai ekonomi akibat kehilangan karbon per tahun sebesar 2,7-6,7 milyar.

Upaya perbaikan ekosistem melalui rehabilitasi harus dilakukan untuk kembali meningkatkan kualitas ekosistem mangrove. Hasil penelitian sebelumnya menargetkan adanya 1.102 ha lahan yang harus direhabilitasi dengan biaya sebesar Rp 30.658.191.000,. Biaya ini akan menjadi Rp 35.008.887.000,- saat ditambahkan biaya pembentukan kawasan konservasi dan biaya pengelolaan.

Perhitungan kerugian akibat kerusakan ekosistem mangrove di Muara Gembong, Teluk Jakarta dan potensi biaya akibat rehabilitasi saat ini masih mempertimbangkan satu jasa ekosistem yang ada yaitu kemampuan ekosistem mangrove menyerap dan menyimpan karbon. Nilai ini akan makin bertambah bila jasa ekosistem lainnya juga diperhitungkan seperti penangkapan biota bernilai ekonomi, kayu bakar, penahan abrasi dan biodiversitas.

\section{UCAPAN TERIMA KASIH}

Tulisan ini merupakan bagian hasil dari kegiatan penelitian di Pusat Riset Kelautan, Badan Riset Kelautan dan Perikanan, Kementerian Kelautan dan Perikanan pada tahun anggaran 2018 (Riset model 
Pendekatan Kerusakan dan Restorasi Ekosistem Mangrove Muara Gembong) dan 2019 (Penyusunan Kertas Kerja Kebijakan Penghitungan Kerugian dan Kerusakan Ekosistem Pesisir Akibat Perubahan Iklim). Semua penulis sebagai kontributor utama.

\section{DAFTAR PUSTAKA}

Alongi, D. (2014). Carbon Cycling and storage in mangrove forest. Annu. Rev. Mar. Sci, 6(1), 195-219. DOI:10.1146/annurevmarine-010213-135020.

Ati, R. N. A., Rustam, A., Kepel, T. L., Sudirman, N., Kusumaningtya, M. A., Daulat, A., Mangindaan, P., Salim, H. L., \& Hutahaean, A.A. (2014). Stok Karbon dan StrukturKomunitas Mangrove SebagaiBlue Carbon di TanjungLesung, Banten. Jurnal Segara, 10(2), 98-171.

Brown, S., Nicholls, R. J., Hanson, S., Brundrit, G., Dearing, J. A., Dickson, M. E., Gallop, S. L., Gao, S., Haigh, I. D., Hinkel, J., Jiménez, J. A., Klein, R. J. T., Lázár, W. K, A. N., Neves, C. F., Newton, A., Pattiaratachi, C., Payo, A., Pye, K., Sánchez-Arcilla, A., Siddall, M., Shareef, A., Tompkins, E. L., Vafeidis, A. T., van Maanen, B., Ward, P. J., \& Woodroffe, C. D. (2014a). Shifting perspectives on coastal impacts and adaptation. Nature Climate Change, 4(9), 752755. DOI:10.1038/nclimate2344

Brown, B., Fadillah, R., Nurdin, Y. , Soulsby, I., \& Ahmad, R. (2014b). Community based ecological mangrove rehabilitation (CBEMR) in Indonesia. Sapiens, 7(2).

Cahyaningrum, S. T., Hartoko, A., \& Suryanti. (2014). Biomassa Karbon Mangrove Pada Kawasan Mangrove PulauKemujan Taman Nasional Karimunjawa Mangrove. Diponegoro Journal of Maquares, 3(3), 34-42.

Dharmawan, I. W. S., \& Siregar, C. A. (2008). Karbon tanah dan pendugaan karbon tegakan Avicennia marina (Forsk.) Vierh. Di Ciasem, Purwakarta. Jurnal Penelitian Hutan dan Konservasi Alam 5(4), 317-328.

Donato, D. C., Kauffman, J. B., Murdiyarso, D., Kurnianto, S., Stidham, M., \& Kanninen, M. (2011). Mangroves among the most carbon-rich forests in the tropics. Nature Geoscience, 4(5),
293-297. DOI:10.1038/ngeo1123

Duke, N. C. (2016). Oil spill impacts onmangroves: Recommendations for operational planning and action based on a global review. Marine Pollution Bulletin, 109(2), 700-715. DOI:10.1016/j. marpolbul.2016.06.082.

Formard, F., Puig, H., Mougin, E., Marty, G., Betoulle, J. L., \& Cadamuro, L. (1998). Structure, aboveground biomass and dynamics of mangrove ecosystems: New data from French Guiana. Oecologia, 115(1), 39-53. DOI:10.1007/ s004420050489.

Getter, C,D., Scott, G. I., \& Michel, J. (1981). The effects of oil spills on mangrove forests: a comparison of five oil spill in the Gulf of Mexico and The Caribbean Sea. International Oil Spill Conference Proceedings, 1981(1), 535-540. DOI:10.7901/2169-3358-1981-1-535.

Giesen, W., Wulffraat, S., Zieren, M., \& L. Scholten. (2006). Mangrove guidebook for Southeast Asia. RAP Publication 2006/2007. FAO and Wetlands International. $268 \mathrm{p}$.

Haneda, N. F., \& Suheri, M. (2018). Hama mangrove di kecamatan Batu Ampar, Kabupaten Kubu Raya, Kalimantan Barat. Jurnal Silvikultur Tropika, 9 (1), 16-23.

Hartoko, A., Cahyaningrum, S., Febrianti, D. A., Ariyanto, D., \& Suryanti. (2015). Carbon Biomass Algorithms Development for Mangrove Vegetation in Kemujan, Parang Island Karimunjawa National Park and Demak Coastal Area - Indonesia. Procedia Environmental Sciences, Basic Researches in The Tropical and Coastal Region Eco Developments. 23, 39-47. DOI:10.1016/j.proenv.2015.01.007

IPCC. (2014). Summary for policymakers. In: Climate Change 2014: Impacts, Adaptation, and Vulnerability. Part A: Global and Sectoral Aspects. Contribution of Working Group II to the Fifth Assessment Report of the Intergovernmental Panel on Climate Change [Field, C.B., V.R. Barros, D.J. Dokken, K.J. Mach, M.D. Mastrandrea, T.E. Bilir, M. Chatterjee, K.L. Ebi, Y.O. Estrada, R.C. Genova, B. Girma, E.S. Kissel, A.N. Levy, S. MacCracken, P.R. Mastrandrea, and L.L. Whit (eds.)]. Cambridge 
University Press, Cambridge, United Kingdom and New York, NY, USA, pp. 1-32.

Jerath, M. C., Bhat, M., Rivera-Monroy, V. H., Castaneda-Moya, E., Simard, M., \& Twilley, R. R. (2016). The role of economic, policy, and ecological factors in estimating the value of carbon stocks in Everglades mangrove forests, South Florida, USA. Environmental Science \& Policy 66(4), 160-169. DOI:10.1016/j. envsci.2016.09.005.

Kairo, J. G., Bosire, J., \& Omar, M. (2005). Assessment of the effects of oil spill on the mangrove forests of Port Reitz, Mombasa. Kenya Marine and Fisheries Research Institute, Marine Ecology and Environment Program. 12 pp.

Kepel, T. L., Suryono, D. D., Ati, R. N. A., Salim, H. L., \& Hutahaean, A. A. (2017). Nilai penting dan estimasi nilai ekonomi simpanan karbon vegetasi mangrove di Kema, Sulawesi Utara. Jurnal Kelautan Nasional 12(1), 19-26.

Kepel, T. L., Ati, R. N. A., Rustam, A., Rahayu, Y. P., Kusumaningtyas, M. A., Daulat, A., Suryono, D. D., Sudirman, N., Adi, N. S., Mantiri, D. M. H., \& Hutahaean, A. A. (2019). Cadangan karboon ekosistem mangrove di Sulawesi Utara dan implikasinya pada aksi mitigasi perubahan iklim. Jurnal Kelautan Nasional 14(2), 87-94.

Linham, M. M., \& Nicholls, R. J. (2010). Technologies for Climate Change Adaptation. Coastal Erosion and Flooding. Zhu, X (edited). UNEP Risø Centre on Energy, Climate and Sustainable Development, Risø DTU National Laboratory for Sustainable Energy. Denmark. ISBN : 97887-550-3855-4. URL :http://tech-action.org/

McCrea-Strub, A., Zeller, D., Sumaila, R., Nelson, J., Balmford, A., \& Pauly, D. (2011). Understanding the cost of establishing marine protected areas. Marine Policy, 35(1), 1-9. DOI:10.1016/j. marpol.2010.07.001

Murray, B.C., Pendleton, L., Jenkins, W. A., \& Sifleet, S. (2011). Green payments for blue carbon economic incentives for protecting threatened coastal habitats. Nicholas Institute for Environmental Policy Solutions, Duke University. $42 \mathrm{p}$.
Murdiyarso, D., Purbopuspito, J., Kauffman, J. B., Warren, M. W., Sasmito, S. D., Donato, D. C., Manuri, S., Krisnawati, H., Taberima, S., \& Kurnianto, S. (2015). The potential of Indonesian mangrove forests for global climate change mitigation. Nature Climate Change 5(12), 1089-1092. DOI:10.1038/nclimate2734.

Nguyen, T.P., Luom, T. T., \& Parnell, K. E. (2017). Mangrove transplantation in Brebes Regency, Indonesia: Lessons and recommendations. Ocean \& Coastal Management 149, 12-21. DOI:10.1016/j.ocecoaman.2017.09.006.

Prayogi, H., Wijayanto, D., \& Raysina, N. (2017). Kajian valuasi ekonomi hutan mangrove di Desa Pantai Mekar, Kecamantan Muara Gembong, Kabupaten Bekasi. Prosiding Seminar Nasional Hasil-Hasil PenelitianPerikanan dan Kelautan ke-VI. FakultasPerikanan dan IlmuKelautan UNDIP, pp. 47-54. ISBN 2339-0883.

Rahmasari, S. N., Agus, F., Muningsih, D., \& Gantini, W. T. (2019). Studi keanekaragaman mangrove Patai Mekar Kecamatan Muara GembongKAbupaten Bekasi. Jurnal Resolusi Konflik, CSR dan Pemberdayaan, 4(1), 35-41.

Sidik, F., Adame, M. F., \& Lovelock, C. E. (2019). Carbon sequestration and fluxes of restored mangroves in abandoned aquaculture ponds. Journal of the Indian Ocean Region, 15(2), 177192. https://doi.org/10.1080/19480881.2019.16 05659

UNEP \& CIFOR. (2014). Guiding principles for delivering coastal wetland carbon projects. United Nations Environment Programme, Nairobi, Kenya and Center for International Forestry Research, Bogor, Indonesia, 57pp.

Warsono, A. (2019). Pohon mangrove di ekowisata muara gembong diserang ulat bulu. https://metro. tempo.co/read/1242002/pohon-mangrove-diekowisata-muara-gembong-diserang-ulat-bulu/ full\&view=ok. Diakses pada November 2019.

World Bank, Ecofys \& Vivid Economics. (2017). State and Trends of Carbon Pricing 2017 (November), by World Bank, Washington, DC. Doi: 10.1596/978-1-4648-1218-7 License: Creative Commons Attribution CC BY 3.0 IGO. 
